\section{Iron Supply for Erythropoiesis in the Rabbit}

\author{
Antonio Celada, Sunday Stray, Muraki Sivarajan, and \\ Clement Finch \\ Department of Medicine, Division of Hematology and \\ Department of Anesthesiology, University of Washington, ZD-20, \\ Seattle, Washington 98195
}

A

bstract. Marrow radioiron uptake and marrow blood flow were measured in order to evaluate iron supply for erythropoiesis. Normal, phenylhydrazinetreated and bled animals were studied. The plasma iron turnover of seven normal rabbits was $1.49 \pm 0.22 \mathrm{mg} / \mathrm{dl}$ whole blood per $\mathrm{d}$, of 11 rabbits treated $4 \mathrm{~d}$ before with phenylhydrazine was $5.16 \pm 1.81$, and of four bled animals the plasma iron turnover was $3.75 \pm 1.61$. The cardiac output and the percentage of blood flow to the marrow was increased in phenylhydrazine-treated and bled animals. Marrow iron flow in phenylhydrazine-treated animals was $38.3 \pm 32.6 \mu \mathrm{g} / \mathrm{min}$ per $\mathrm{kg}$ as compared with control values of $7.0 \pm 1.3(P<0.01)$. This was due to an increase in marrow flow, an increase in plasma iron, and an increase in plasmatocrit. In bled animals, in spite of an increased marrow blood flow, marrow iron flow of $7.3 \pm 2.2$ was similar to that of control animals due to a lower plasma iron concentration. The calculated marrow iron extraction of $3.7 \pm 2.4 \%$ in phenylhydrazine-treated animals was not different from that of control animals of $4.3 \pm 1.1$, whereas extraction was increased in bled animals to $7.9 \pm 1.3(P<0.01)$. In additional studies of transfused animals, acutely induced anemia was associated with an increased cardiac output, but also with a relative decrease in marrow flow, which left marrow iron supply unaffected. It would appear from these studies that an important mechanism for meeting the increased iron requirement of the hyperplastic erythroid marrow is an increase in marrow blood flow.

\section{Introduction}

Internal iron delivery is determined by the relation between available iron supply and tissue requirements. Supply is rep-

\footnotetext{
Address correspondence to Dr. Finch.

Received for publication 15 November 1982 and in revised form 31 January 1984.
}

J. Clin. Invest.

(C) The American Society for Clinical Investigation, Inc.

0021-9738/84/07/0161/04\$\$1.00

Volume 74, July 1984, 161-164 resented by the amount of transferrin iron reaching the tissue per unit time and by the degree of saturation of transferrin with iron (1). Previous studies have emphasized the importance of the amount of diferric transferrin present, since this complex is capable of delivering much more iron than monoferric transferrin $(2,3)$. The total number of iron-containing transferrin molecules vs. membrane receptor number is also important, since iron uptake will be decreased if the number of iron-loaded transferrin molecules is insufficient to saturate receptors. In examining these various relationships, it is essential to measure blood flow, about which little is known.

\section{Methods}

New Zealand male rabbits weighing between 2.8 and $3.2 \mathrm{~kg}$ were maintained on a Purina rabbit chow diet (Ralston Purina Co., St. Louis, $\mathrm{MO})$. Some of these animals were studied in their basal state, and some were studied $4 \mathrm{~d}$ after erythropoiesis had been stimulated by the intravenous injection of acetylphenylhydrazine $(30 \mathrm{mg} / \mathrm{kg})$. Additional animals were bled $10-20 \mathrm{ml} / \mathrm{kg}$ three to five times with replacement of plasma during a 2-wk period before the study. Reticulocyte counts of normal operated animals were $87 \pm 46 \times 10^{3} / \mu$ l, of animals on the fourth day after phenylhydrazine injections were $704 \pm 239$, and of bled animals were $585 \pm 123$.

On the day of the experiment, animals were anesthetized by the intramuscular injection of a 1:1 mixture of Vetalar (Parke Davis \& Co., Morris Plains, NJ) and Rompun (Haver-Lockhart, Shawnee, KS) at a dosage of $50 \mathrm{mg} / \mathrm{kg}$ and $10 \mathrm{mg} / \mathrm{kg}$, respectively. Measurements were made of plasma iron turnover (PIT) ${ }^{1}$ employing radioiron and of marrow blood flow employing isotopically-labeled microspheres. At the end of the experiment, animals were killed by exsanguination and the skin and viscera were removed. The remaining carcass was autoclaved overnight at a temperature of $130^{\circ} \mathrm{C}$ and a pressure of $1.4 \mathrm{~kg} / \mathrm{m}^{2}$. After that, the individual bones were removed and cleaned. The prolonged autoclaving softened the bones to the extent that they could be packed at the bottom of plastic tubes.

The femurs of some animals were processed before autoclaving so as to separate marrow from bone. The femurs were first cleaned of surrounding tissues and then cut longitudinally using a small rotary saw. Samples of cortical bone and of marrow were weighed and radioactivity was determined. From the relative weight of bone vs. marrow and their relative activities, the distribution of radioiron and of labeled microspheres were determined. Less than $1 \%$ of radioiron in the femur was found in the bone $(0.98 \pm 0.18 \%$ in five normal animals and

1. Abbreviations used in this paper: $\mathrm{CO}$, cardiac output; PIT, plasma iron turnover. 
$0.85 \pm 0.22 \%$ in five animals with increased erythropoiesis). On the other hand, some $15.2 \pm 2.8 \%$ of microspheres were localized in the bone of normal animals and $13.4 \pm 1.5 \%$ in animals with increased erythropoiesis. It appeared that iron was taken up exclusively by the marrow, but that some $15 \%$ of blood flow was to bone rather than marrow.

Gamma-emitting isotopes $\left({ }^{59} \mathrm{Fe},{ }^{57} \mathrm{Co},{ }^{113} \mathrm{Sn}\right)$ were differentially counted in a Packard model 5330 counter (Packard Instrument Co., Downers Grove, IL). Plasma samples containing ${ }^{59} \mathrm{Fe}$ and/or ${ }^{55} \mathrm{Fe}$ were prepared by adding $0.25 \mathrm{ml}$ plasma to $0.5 \mathrm{ml} 0.1 \mathrm{~N}$ perchloric acid and were then centrifuged. $10 \mathrm{ml}$ of aquasol (New England Nuclear, Boston, MA) was added to $0.5 \mathrm{ml}$ of the supernatant and the samples were counted in a Tricarb scintillation spectrophotometer (Packard, model 2405 , Packard Instrument Co.). Tissues and red cells containing ${ }^{59} \mathrm{Fe}$ and/or ${ }^{55} \mathrm{Fe}$ were wet ashed and prepared for liquid scintillation counting by the methods of Eakins and Brown (4). Appropriate corrections were made for cross counting and for geometry.

Plasma iron and total iron-binding capacity were determined by standard methods $(5,6)$. Hematocrits were determined by the micro technique and the red cell number by particle counting (Coulter electronic counter, model B, Coulter Electronics, Inc., Hialeah, FL). Reticulocyte percentage was determined by examining 1,000 red cells, each on two different slides, and was converted through the red cell count to reticulocytes per microliter of blood.

Measurements of blood flow. Microspheres labeled with ${ }^{57} \mathrm{Co}$ and ${ }^{113} \mathrm{Sn}$ with a size of $15.2 \pm 1.0 \mu \mathrm{m}$ and $15.6 \pm 1.4 \mu \mathrm{m}$, respectively (New England Nuclear), were used, since they had been shown not to shunt through vascular anastomosis in rabbit bones (7). With the animal under anesthesia, between four- and eight-million microspheres were injected by needle directly into the left side of the heart. ${ }^{2}$ Beginning $30 \mathrm{~s}$ before microsphere injection and continuing 2 min afterward, arterial blood was withdrawn by pump from the central artery of the ear at a rate of $3.5 \mathrm{ml} / \mathrm{min}$. This sample, along with the weighed standard injection, was counted. Cardiac output (CO) was determined according to the following formula: $\mathrm{CO}(\mathrm{ml} / \mathrm{min})=$ blood removal rate $(\mathrm{ml} / \mathrm{min})$ $\times$ (counts injected)/(counts removed). The percentage of the total flow going to the marrow was obtained by counting total skeletal radioactivity and by relating it to the total activity injected. Marrow blood flow (\%) $=$ skeletal activity $\times 100 \times \mathrm{F} /$ counts injected. In this calculation, a factor correction for the blood flow (F) of 0.85 in the normal and 0.87 in anemic animals was made for the portion of activity localized in the bone. Blood flow in $\mathrm{ml} / \mathrm{min}$ per $\mathrm{kg}$ was then determined according to the formula: Marrow flow $(\mathrm{ml} / \mathrm{min}$ per $\mathrm{kg})=\mathrm{CO}(\mathrm{ml} / \mathrm{min}$ per $\mathrm{kg})$ $\times$ marrow flow $(\%) / 100$. In order to evaluate uniformity of microspheres and radioiron distribution through the skeleton, determinations were made in eight normal rabbits and in 10 animals with increased erythropoiesis. Distribution of radioiron between left and right side bones of the body were virtually identical $(r=0.98)$. A similar correlation was found with microspheres $(r=0.97)$.

Ferrokinetic measurements. Ferrokinetic measurements were carried out in animals as previously described (8). $1 \mathrm{ml}$ of a solution of ferrous sulfate that contained $1-3 \mu \mathrm{Ci}$ radioiron in $1.0 \mu \mathrm{g}$ iron at $\mathrm{pH} 2$ was injected intravenously over a 5 -min period in the marginal vein of the ear. Thereafter, five or six samples of $1 \mathrm{ml}$ each were drawn from the central artery of the ear, with sampling time being adjusted to extend beyond the anticipated $T^{1 / 2}$ radioiron disappearance. Blood was either placed on ice and spun within $1 \mathrm{~h}$, or in animals with high numbers of

2. In the seven animals subjected to exchange transfusion, microspheres were injected directly into the left atrium by a catheter, which had been implanted 2-3 wk previously. circulating reticulocytes it was rapidly centrifuged with separation of red cells and plasma within $3 \mathrm{~min}$ of the time the sample was obtained. Blood samples at $10 \mathrm{~min}$ and at the approximate $\mathrm{T}^{1 / 2}$ were analyzed for plasma iron. When $>90 \%$ of radioiron had disappeared from circulating plasma, animals were killed by exsanguination in saline perfusion over a 10-15-min period.

The effectiveness of perfusion in removing radioactivity due to labeled red blood cells was studied in three animals compared with three others in which perfusion was not carried out. The percentage of intravenously injected ${ }^{59} \mathrm{Fe}$-labeled red blood cells remaining in the skeleton, liver, and spleen in the nonperfused animals was $3.5 \pm 0.4,9.6 \pm 2.2$, and $0.3 \pm 0.1$, and in the perfused animals was $0.3 \pm 0.1,1.6 \pm 1.8$, and $0.09 \pm 0.01$, respectively. Accordingly, no correction was made for the $0.3 \%$ residual red cell activity in calculating the amount of radioiron localized in the skeleton.

Plasma iron turnover was calculated according to the formula previously described (9): PIT (mg/dl whole blood per day) = plasma iron $(\mu \mathrm{g} / \%) \times(100-\mathrm{Hct} \times 0.9) / \mathrm{T}^{1 / 2}(\mathrm{~min}) \times 100$. The plasma iron used in this formula was the extrapolated value at the $T^{1} / 2$ disappearance of radioiron (8). Red cell activity was determined from the counts per milliliter of washed red cells, the hematocrit, and the blood volume, which was assumed to be $58 \mathrm{ml} / \mathrm{kg}$ (mean value obtained in 10 normal animals). The iron supply to the erythroid marrow was calculated according to the following formula: marrow iron flow ( $\mu \mathrm{g} / \mathrm{min}$ per $\mathrm{kg}$ ) $=$ plasma iron $(\mu \mathrm{g} / \mathrm{dl}) \times$ marrow plasma flow $(\mathrm{ml} / \mathrm{min}$ per $\mathrm{kg})$. Plasma iron uptake by the bone marrow was calculated from the PIT and from the proportion of injected radioiron localized in the marrow at a time when $90 \%$ of radioactivity had left the plasma. Marrow iron uptake $(\mathrm{mg} / \mathrm{dl}$ whole blood per day $)=$ PIT $(\mathrm{mg} / \mathrm{dl}$ whole blood per day $)$ $\times$ marrow radioactivity $(\%)$. The percentage of iron extracted from plasma that circulated through the bone marrow was calculated from the iron uptake by the marrow divided by the iron flow through the marrow, according to the following formula: extraction $(\%)=$ marrow iron uptake $(\mu \mathrm{g} / \mathrm{min}$ per $\mathrm{kg}) \times 100 /$ marrow iron flow $(\mu \mathrm{g} / \mathrm{min}$ per $\mathrm{kg})$. The rate of movement of erythrocytes into blood in animals with phenylhydrazine anemia was determined from changes in circulating red cell radioactivity after $>90 \%$ of radioiron had disappeared from the plasma. Over a 2-h period, red cell activity increased by $<5 \%$. On the basis of this, it was not considered necessary in calculations of relative uptake by marrow and by blood to make corrections for that radioactivity which moved from marrow to blood during the study.

Statistical analysis. Nonparametric tests were employed: the Wilcoxon for paired values, the Mann-Whitney for unpaired values, and the Spearman rank correlation (10).

\section{Results}

Erythropoiesis in seven normal rabbits was characterized by ferrokinetic measurements (Table I). These animals had a mean plasma iron of $155 \pm 27 \mu \mathrm{g} / \mathrm{dl}$ and a plasma iron turnover of $1.49 \pm 0.22 \mathrm{mg} / \mathrm{dl}$ whole blood $/ \mathrm{d}$. These values were similar to previous results (11), and there was the expected relationship between transferrin saturation and PIT $(r=0.71, P<0.01)$. Mean erythron iron uptake in normal animals was $0.92 \mathrm{mg} / \mathrm{dl}$ whole blood/d of which $77 \%$ was in the marrow and $23 \%$ in the circulating blood. Mean cardiac output was $107 \mathrm{ml} / \mathrm{min}$ per $\mathrm{kg}$, of which $6.4 \%$ went to the erythroid marrow. Only $4.3 \%$ of transferrin iron passing through the marrow cavity was extracted by the marrow. 
Table I. Values of the Different Parameters of the Normal, Phenylhydrazine-treated, and Bled Animals

\begin{tabular}{|c|c|c|c|}
\hline & \multirow{2}{*}{$\begin{array}{l}\text { Normal } \\
(n=7)\end{array}$} & \multicolumn{2}{|c|}{$\begin{array}{l}\text { Phenylhydrazine-bled } \\
\text { animals treated }\end{array}$} \\
\hline & & $n=11$ & $n=4$ \\
\hline Hematocrit (\%) & $38 \pm 2$ & $22 \pm 5^{*}$ & $21 \pm 3^{*}$ \\
\hline Plasma iron $(\mu g / d l)$ & $155 \pm 27$ & $212 \pm 105^{*}$ & $68 \pm 27^{*}$ \\
\hline Transferrin saturation (\%) & $57 \pm 12$ & $63 \pm 28$ & $18 \pm 8$ \\
\hline $\mathrm{T}^{1 / 2}(\min )$ & $70 \pm 14$ & $33 \pm 15^{*}$ & $15 \pm 2^{*}$ \\
\hline \multicolumn{4}{|l|}{ Total PIT $(\mathrm{mg} / \mathrm{dl}$ whole } \\
\hline blood/d) & $1.49 \pm 0.22$ & $5.61 \pm 1.81^{*}$ & $3.73 \pm 1.61^{*}$ \\
\hline $\begin{array}{l}\text { Marrow uptake } \\
(\mathrm{mg} / \text { dl whole blood/d })\end{array}$ & \multicolumn{2}{|c|}{ Marrow uptake } & $1.45 \pm 0.63^{*}$ \\
\hline \multicolumn{4}{|l|}{ Blood uptake } \\
\hline \multicolumn{4}{|l|}{ Cardiac output } \\
\hline$(\mathrm{ml} / \mathrm{min} / \mathrm{kg})$ & $107 \pm 12$ & $174 \pm 71^{*}$ & $153 \pm 50$ \\
\hline Marrow flow (\% of $\mathrm{CO}$ ) & $6.4 \pm 0.8$ & $12.3 \pm 5.3^{*}$ & $8.6 \pm 1.1$ \\
\hline \multicolumn{4}{|l|}{ Marrow Fe flow } \\
\hline \multicolumn{4}{|l|}{ Marrow $\mathrm{Fe}$ extraction } \\
\hline (\% of marrow iron flow) & $4.3 \pm 1.1$ & $3.7 \pm 2.4$ & $7.9 \pm 1.3^{*}$ \\
\hline
\end{tabular}

* $P<0.01$ in relation to the values of normal animals using the Mann-Whitney test.

Similar studies were carried out in 11 animals with anemia produced by phenylhydrazine. Mean PIT was increased to 5.61 $\mathrm{mg} / \mathrm{dl}$ whole blood/d. $44 \%$ of the erythron uptake of $3.39 \mathrm{mg} /$ $\mathrm{dl}$ whole blood/d was in the circulating blood. $\mathrm{CO}$ was increased $62 \%$ and the proportion of blood flowing through the marrow increased by $92 \%$. This increased flow along with the elevated plasma iron resulted in a more than fivefold increase in marrow iron flow. Percentage extraction of radioiron from blood circulating through the marrow was $3.7 \%$.

Four bled animals with the same degree of anemia had a PIT of $3.73 \mathrm{mg} / \mathrm{dl}$ whole blood/d, which was intermediate between normal and phenylhydrazine-treated animals. $\mathrm{CO}$ was increased $43 \%$ and the proportion of blood going to the marrow was also increased by $34 \%$. Marrow iron flow was not different to the controls but the percentage extraction increased approximately twofold. In the 15 animals with increased erythropoiesis, iron taken up by the marrow was well correlated with PIT ( $r$ $=0.82, P<0.001)$. Bone marrow flow showed a correlation with the PIT $(r=0.59, P<0.01)$. No correlation was found between the degree of anemia and bone marrow blood or iron flow.

Because anemia itself might produce changes in marrow blood flow and iron extraction, an additional study was carried out in seven animals. Exchange transfusion lowered their hematocrit to $21 \pm 3 \%$. PIT carried out before and immediately after exchange transfusion was not significantly affected, i.e., $2.1 \pm 0.9 \mathrm{mg} / \mathrm{dl}$ whole blood/d before and $2.1 \pm 0.9$ afterward. $\mathrm{CO}$ was increased by $70 \%$, but bone marrow flow was decreased by $38 \%$, which left marrow iron flow essentially unchanged, i.e.,
$12.2 \pm 5.8$ and $14.4 \pm 6.4 \mu \mathrm{g} / \mathrm{kg}$ per min. Marrow iron extraction was not significantly affected ( $4.6 \pm 1.8$ vs. $4.0 \pm 3.3)$.

\section{Discussion}

In certain anemias associated with erythroid hyperplasia, there is evidence that a relative iron deficiency exists. The expected macrocytosis characteristic of the stimulated erythron may not be seen despite a normal plasma iron concentration, which suggests a limitation in hemoglobin production by the expanded population of erythroid precursors (12). Likewise, red cell protoporphyrin, an indicator of red cell iron deficiency, may increase when the production rises to over five times normal, despite a normal plasma iron or transferrin saturation (13), which indicates a relative deficiency in iron supply. The present studies were undertaken to examine iron flow to the marrow under normal conditions and with erythroid hyperplasia at different levels of plasma iron.

Rabbits were selected, since their iron kinetics had been studied in detail (11) and since the behavior of the transferrin receptor system closely resembled that of man (Huebers, $\mathrm{H}$., and C. A. Finch, unpublished observations). By measuring the PIT and localization of radioiron in body tissues, it was possible to quantitate iron uptake, and more especially, the uptake of the erythroid marrow and of circulating reticulocytes. For measurement of $\mathrm{CO}$, a microsphere technique was employed whereby the labeled spheres were injected by needle directly into the left side of the heart (14). The microsphere distribution was symmetrical on the two sides of the skeleton, which indicated a uniform distribution. Within the skeleton itself, some $85 \%$ of the microspheres were found in the marrow as compared with bone. These results in rabbits were similar to those reported in dogs by Gross et al. (7).

The cardiac output of $120 \pm 35 \mathrm{ml} / \mathrm{min}$ per $\mathrm{kg}$ in normal anesthetized animals was somewhat below that reported by Syftestad and Boelkins (15) of $165 \pm 24 \mathrm{ml} / \mathrm{min}$ per $\mathrm{kg}$ in unanesthetized operated animals. The marrow flow of $10.7 \%$ of $\mathrm{CO}$ was similar to that described in other reports $(7,15)$. The iron marrow blood flow greatly exceeded marrow requirements for iron and a plasma iron extraction of $4.3 \%$ was calculated.

The production of hemolytic anemia by phenylhydrazine is associated with an initial destruction of $\sim 20 \%$ of the circulating red cell mass each day (12). Proliferation of the erythroid marrow follows with a reticulocytosis in circulation and a rapid recovery of the hematocrit over a period of 7-10 d. The plasma iron is elevated and the transferrin is nearly saturated over the first 2$3 \mathrm{~d}$ and thereafter returns gradually to normal or subnormal levels. Our study was made on the fourth day, when anemia was severe and red cell proliferation marked, with a mean circulating reticulocyte count of eight times basal. A conspicuous finding was that the proportion of erythron radioiron taken up by circulating reticulocytes had doubled, i.e., an increase from $22 \%$ in normal animals to $44 \%$. Thus, an increased proportion of radioiron uptake is independent of marrow flow. Actual mar- 
row iron uptake was increased only three times. Nevertheless, marrow iron flow had increased more than fivefold, due to the increase in plasma iron concentration, in plasmatocrit, and in marrow blood flow. Thus, available iron increased in these animals more than did marrow requirements. The opposite situation occurred in four bled animals where iron supply was reduced while marrow requirements were increased.

Comparing phenylhydrazine-treated and bled animals there is a considerably greater increase in PIT, in marrow iron uptake, and in reticulocyte output of the animals undergoing increased red cell breakdown. While there has been some question as to whether hemolysis in some special way augments erythropoiesis (16), it seems reasonable to explain the difference by the limited supply of iron. Not only is hemoglobin synthesis within the individual cell reduced when iron supply decreases, but there is also ample evidence that stem cell maturation is markedly curtailed in iron deficient anemia as compared with hemolytic anemia (17). That such an effect was demonstrated in bled animals when iron extraction was only $8 \%$ suggests that the capacity of the marrow to remove iron is limited.

The increased blood flow to the marrow was helpful in balancing the increased marrow requirements. Previous studies with an isolated femur from phenylhydrazine-treated animals have also indicated an increased flow in this in vitro experimental setting (18). Thus, marrow flow would seem to behave similarly to the flow in other tissues and be regulated by metabolic activity.

Obviously, other factors can influence blood flow, and it was of concern that anemia per se might have an influence on marrow flow as well as on erythropoiesis. $\mathrm{CO}$ has been observed by Richardson and Guyton (19) to increase in dogs whose hematocrits were rapidly lowered by blood exchange without volume exchange. However, our animals made acutely anemic by exchange transfusion with plasma showed no change in marrow iron supply, despite some immediate change in cardiac output. Thus, it was the increased erythropoiesis rather than the anemia that was responsible for increased marrow flow.

\section{Acknowledgment}

We wish to thank Dr. J. B. Bassingthwaighte, Center for Bioengineering, University of Washington, Seattle, WA, for his advice concerning microspheres, and Steve Sato, from the Bob Hope International Heart Research Institute, Seattle, WA.

This research was supported by grant HL-06242 from the National Institute of Heart, Lung and Blood, National Institutes of Health. Computations assistance was provided by CLINFO computer systems and was funded under Clinical Research grant RR-37.

\section{References}

1. Finch, C. A. 1982. Erythropoiesis, erythropoietin and iron. Blood. 60:1241-1246.
2. Huebers, H., B. Josephson, E. Huebers, E. Csiba, and C. A. Finch. 1981. Uptake and release of iron from human transferrin. Proc. Natl. Acad. Sci. USA. 78:2572-2576.

3. Huebers, H. A., E. Csiba, E. Huebers, and C. A. Finch. 1983. Competitive advantage of diferric transferrin in delivering iron to reticulocytes. Proc. Natl. Acad. Sci. USA. 80:300-304.

4. Eakins, J. D., and E. A. Brown. 1966. An improved method for the simultaneous determination of iron 55 and iron 59 in blood by liquid scintillation counting. Int. J. Appl. Radiat. Isot. 17:391-397.

5. The International Committee for Standardization in Hematology. 1971. Proposed recommendations for measurement of serum iron in human blood. Blood. 37:598-600.

6. Cook, J. D. 1970. An evaluation of absorption methods for measurement of plasma iron-binding capacity. J. Lab. Clin. Med. 76:497506.

7. Gross, P. M., D. D. Heistad, and M. L. Marcus. 1979. Neurohumoral regulation of blood flow to bones and marrow. Am. J. Physiol. 237: $\mathrm{H} 440-\mathrm{H} 448$.

8. Bauer, W., S. Stray, H. Huebers, and C. A. Finch. 1981. The relationship between plasma iron and plasma iron turnover in the rat. Blood. 52:239-242.

9. Finch, C. A., K. Deubelbeiss, J. D. Cook, J. W. Eschbach, L. A. Harker, D. D. Funk, G. Marsaglia, R. S. Hillman, S. Slichter, J. W. Adamson, A. Ganzoni, and E. R. Giblett. 1970. Ferrokinetics in man. Medicine (Baltimore). 49:17-53.

10. Snedecor, G. W., and W. G. Cochrane. 1967. Statistical Methods. Iowa State University Press, Ames, IA. Sixth ed. 663 pp.

11. Huebers, H., D. Uvelli, A. Celada, B. Josephson, and C. A. Finch. 1982. The basis of plasma iron exchange in the rabbit. J. Clin. Invest. 70:769-779.

12. Jacobs, P., and C. A. Finch. 1971. Iron for erythropoiesis. Blood. 37:220-230.

13. Langer, E. E., R. G. Haining, R. F. Labbe, P. Jacobs, E. F. Crosby, and C. A. Finch. 1972. Erythrocyte protoporphyrin. Blood. 40:112-128.

14. Archie, J. P., D. E. Fixler, D. J. Ullyot, J. I. E. Hoffman, J. R. Utley, and E. C. Carlson. 1973. Measurement of cardiac output with an organ trapping of radioactive microspheres. J. Appl. Physiol. 35:148156.

15. Syftestad, G. T., and J. N. Boelkins. 1980. Effect of hemorrhage on blood flow to marrow and osseous tissue in conscious rabbits. Am. J. Physiol. 238:H360-H364.

16. Sanchez-Medal, L., L. Duarte, and J. Labardini. 1970. Hemolysis and erythropoiesis. VI. A comparative study of the utilization of hemoglobin iron and transferrin iron by the erythropoietic tissue. Blood. 35:721-726.

17. Kimura, H., C. A. Finch, and J. W. Adamson. 1983. Iron deficiency (ID): quantitation of its effects on erythropoiesis in the rat. Blood. 62:123A. (Abstr.)

18. Nichelsen, K. (1969). Hemodynamics in the bone marrow of anemic rabbits with increased hematopoiesis. Acta Physiol. Scand. 77:5257.

19. Richardson, R. Q., and A. C. Guyton. 1959. Effects of polycythemia and anemia on cardiac output and other circulatory factors. Am. J. Physiol. 197:1167-1170. 